\title{
The Role of Government To Build Eco Community
}

\author{
Aju Putrijanti $^{1}$ \\ Faculty of Law , Diponegoro University, Semarang - Indonesia
}

\begin{abstract}
As stated in Article $28 \mathrm{H}$ Consitution on Republic of Indonesia 1945, that every person has rights of good and healthy environment, medical service. The needs of healthy environment in neighborhood is highly demand in a few years. People starts to realize the importance of living in a healthy way. The issue is how the role of governance to build a healthy environment, in order to fulfill the rights of good environment so the people can do the activity without pollution. Government has an important role to make regulations and must be an eco regulations which environment friendly and put the needs of healthy environment as top priority. The regulation of spatial area should be supported with the related regulations and implementation. There should be comprehensive regulations substantively due to the issue. The method of this article is normative approach by analyzed the related regulations and comparative approach. The conclusion is the government has to starts to make an eco regulations to fulfill the needs of healthy environment and regulate the reuse of environment in future.
\end{abstract}

Keywords: Governance; eco community; environment.

\section{Introduction}

The Constitution of Republic of Indonesia 1945 in Article $28 \mathrm{H}$ stated that every person has rights of good and healthy environment, medical care. The management of environment has begun since Government stipulated the Law No 4 Year 1982 of Environmental Law, then replaced by Law No 23 Year 1997 of Management of the Environment, and the last is Law No 32 Year 2009 of The Safety and Management of Environment (herein after is The Law). The aims of the law among others is to fulfill and protect the rights of environment as part of human rights.

The government has an authority to makes regulation to implement the Constitution and embody the good and health environment, since they are important for civilization as their rights. The concept of eco community has to introduced, so the people are ready to receive and develop it. In some countries, they have developed eco community, eco village which emphasize the needs of good, clean environment, wastewater management, reuse of environment.

Indonesia is one of the top ten highest countries, which contributes the high carbon emission, so there should be an action by the government, to make regulations to manage the use of carbon. This article explain the important role of government to reduce the carbon emssion by build an eco community. This community use the environment by implement regulations which put the aim to reduce carbon emission, including the comprehensive use of spatial planning, forestry in a proper and right ways, stop illegal loging, deforestation and degradation, increase the public awareness to reduce the carbon emission.

The development of information technology, growth population, politics, economics, modernization which changes the way of people lives, the use of petroleum is increase, the behaviour of people, and many other things impact the environment. This is global phenomenon and needs a global action to ameliorate, has to be supported by the local government with regulations and policies.

The issue is how the role of government to build eco community, in an entirely environment, including the waste management, reuse and pollution.

\section{Methods}

This research is use normative approach by analyzing the related regulations on environment. The positive regulations has an aims and basic princples in general. Normative approach is to study and find the philosophy.Normative approach is using by analyze the primarily material such as regulations, and secondary material are journals, books as references.

\section{Disccusion}

3.1 Government

Government is the highest authority in the State, and should implement the Constitution. The authority to make

*Corresponding author: aputriyanti@yahoo.com 
regulations and policies is important and should followed the principles of good governance as stated in Law No 30 Year 2014 of Governance Administration. The development of modernization and globalization had been influenced the governance to shift from a simple governance become complex governance, including the global issues, corruption, environment, etc. Bierman and Pathberg describes the global governance covered the following issues : first, the emergence of new types of agency and of factors in addition to national government, second, the emergence of new mechanism and institutions of global governance that go beyond traditional forms of state - led, treaty based regimes, third, increasing segmentation and fragmentation of the overall governance system across level and functional spheres.[1]. Indonesia contributes the high carbon emissions, it needs a comprehensive regulations and settlement from multidiscipline konwledge to reduce the carbon emissions.

In the Law No 26 Year 2007 of Spatial Planning gives command to harmonize and manage the nature environment and artificial environment, can gives protection of function and negative effect to the environment as cause of spatial planning in urban area.. In Article 2 of Law No 26 Year 2007 of Spatial Planning as a system based on integrity, congeniality and balance, sustainable, effectiveness, usability, openess, relations, protection of public needs, legal certainty and justice, accountability. This law as a legal basis to manage the environment for the people by respect to the principles.

The governance in era of modernization, there should be increase the efficiency for both horizontally and vertically policy integration. Lafferty offers several suggestions for both, i.e. sectoral strategy for plan, action plan, long-term suistanable strategies for sectoral domain, spesific governing bodies, etc.[2] There has to be a significant strategy cross the boundaries to manage the use of environment. The success of environment management are supports by the comprehensive regulations, action plan and judiciary body.[3]

\subsection{Environment}

The degradation of environment quality is happening everywhere, without exception also in Indonesia. The government had been stipulated the Law No 32 Year 2009 of The Safety and Management of Environment as basic rules to protect, manage, reuse the environment. The growth population become higher than 30 years ago, and it gives impact to the environment, social culture, economic, politics and behaviour, on the other side civilizations needs place, space to live, develop and build community as a human being.

\subsection{Regulations to Build Eco Community}

There is no definite meaning of eco community. In the frame to fulfill the environmental rights, the Government has to make an areas which based on eco community and the aims are to manage and reuse of environment. It starts to make an eco regulations, also to cooperate with private company, local people, respect the local wisdom, and important things is the will from the government to fulfill the environmental rights.
Colin Turpin stated that the function of government are implementation and effectiveness of legislation, while Nancy K.Kubasek et.al says government has to make regulations, adjudication of individual cases brought before administrative law judge and administrative activities.[3] Government has important role from the making the regulations until the law enforcement.

In the regulations, there should be definite meaning of eco community, the aims, sanctions and other related things. Government has an important role to make regulations and policies that manage the environment for urban area by considering the massive growth population. Facing the above, it needs an innovative governance which include society participation.[4]

The regulations and policies should be based on the importance of management and reuse of environment, the needs of urban people .

The development of technology is one of the benefit, it means that people has to use it in order to manage, build and reuse the environment.

To build eco community could be starts by the government to make eco re

gulations, including the prohibition to illegal logging, forest burning and many acts that cause the damage of environment, and should be followed by law enforcement in penal either administrative.

The regulations should determine the area where the eco community will build, definitely it has to supported by the related regulations, such as the regulations of waste management, the reuse of environment, the transportation that will be used in the neighborhood. Even the transportation should not ruins the environment, nevertheless to reduce the pollution.

To build eco community, there are relations between the governance, private sector and people, it needs a comprehensive approach. The comprehensive approach are highly demand, because environment have many subject, such as welfare, industries, economic, policy which also has comprehensive problems and output. [5] The Law No 26 Year 2007 of Spatial Planning characterize the principles of good governance as transparency, participation and accountability. There is a step ahead about the responsibility of the government officer, there should be a mechanism of law if there is abuse of power in the policy made by the government related to the matter.[6] In make eco regulations to build eco community, government should obey the principles of good governance with proper interest.

Government has to develop the environmental governance is an effort to build a mechanism to implement the environmental rule of law become empiric. The principles of good governance become basic in many countries, and has to inspire to build the environmental law. [7]

Besides develop the eco regulations, comprehensive approach, government should develop the informationbased governance, in the context of environmental arena and covers non-profit organization, government agencies, companies which have a wide range product eco-label and sustainability rating the environmental performance and companies.[8] For this purposes, the implementation principle of good governance is important, and the 
development of society awareness to use the environment promptly.

The regulations has to consider about diversity maintenance and optimization of the ecosystem as those are two process which are important .[9] Government has to formulate the regulations as easy to understand, no bias meaning and to mention the type of diversity maintenance that put the reuse of environment properly, and the optimization of ecosystem to put the needs of society as a prior. This emphasize to reduce low carbon emission, for instance the reduce deforestation, illegal logging and educating society to respect the environment. Even respect the environment is related with the culture and behaviour, but it has to put clearly in the regulations by give penal or administrative sanctions.

In Ireland, they build eco village (Cloughjordan) which as an intentional or traditional community using local parcipatory process to use integrally between economic, cultural, social to regenerate social and natural environment. In ecovillage, the people strive to get a good life in various aspect, such as ecological building, alternative energy, community building practice, ecological design and many more.[10]

Dockside Green in BC Canada, is an eco community build with emphasize the creating the well-loved community, urban neighborhood and to protect and nurtures the environment. In Dockside Green also build the wastewater treatment facility, so it can be use for toilet and roof top garden irrigation.[11] They use the development of technology to make the healthy environment for the society.

Internationally, The UN Environment helps the government to build environmental laws and policies to protect environment and to fulfill environmental and human rights obligations, also assiting government to environmental information for decision-making, encourage relations between the government and civilization to develop and implementation of environmental policies.[12]. As environmental issues are vary, the UNEP tried to facilitate the governments to solve the problems, build the strong cooperation among Sate, and give supervision of make the eco regulations.

\section{Conclusion}

To fullfill the environment rights, Government has to starts an action by develop the environmental governance. In the environmental governance, it has to put the principles of good governance and environmental law to make regulations. Eco community has to build based on environmental governance, the rights of environment, maintenance and reuse of environment, and other participatory from concerned parties.
The eco community is one effort to reduce low carbon, as viable option and important learning to society to use and respect the environment. It is important to make regulations of spatial planning and should be harmonized with related regulations. It is the government's duty to make a comprehensive regulations in order to continue the suistanable development.

\section{References}

1. J. Jang, J. Mcsparren, and Y. Rashchupkina, "Global governance: present and future," Palgrave Commun., vol. 2, 2016.

2. M. Kardos, "The reflection of good governance in sustainable development strategies," 8th Int. Strateg. Manag. Conf., vol. 58, pp. 1166-1173, 2012.

3. A'an Efendi, Hukum Penyelesaian Sengketa Lingkungan Di Peradilan Tata Usaha Negara, First. Jakarta: Sinar Grafika, 2016.

4. A. Lima and F. Toni, "Energy Landscapes and Environmentality: Boundaries between Discourses and Practices in Energy Governance," Int. J. Environ. Sci. Dev., vol. 8, no. 9, pp. 673677, 2017.

5. H. Daniel and D. H. Cole, "UCLA Journal of Environmental Law and Policy Climate Change, Adaptation , and Development," 2008.

6. et. a. Maria S.W. Sumardjono, "Sinkronisasi Horizontal 12 Undang-undang Terkait Sumber Daya Alam," in Pengaturan Sumber Daya Alam Di Indonesia Antara yang Tersurat dan Tersirat Kajian Kritis Undang-undang Terkait Penataan Ruang dan Sumber Daya Alam, Second., Yogyakarta: Fakultas Hukum Universitas Gadjah Mada bekerja sama dengan Gadjah Mada University Press, 2014, p. 174.

7. Takdir Rahmadi, Hukum Lingkungan di Indonesia. Jakarta: Rajawali Press, 2016.

8. P. Date, "UC Berkeley UC Berkeley Electronic Theses and Dissertations," 2010.

9. 9. 3. 1. 1. V2, "UCLA Journal of Environmental Law and Policy," 2017.

10. "http://thevillage.ie." .

11. "http://docksidegreen.com.".

12. "https://unenvironment.org." . 